\title{
1109 望性加エにおける流体沺滑举功の有限要表解析
}

\section{Finite Element Analysis of Liquid Lubrication Behavior during Metal Forming Processes}

\author{
○学 小寺 功史（岡大院自然）正 清水一郎（岡大院自然）
}

Norifumi KODERA, Okayama University, 3-1-1 Tsushima-naka, Okayama 700-8530 Ichiro SHIMIZU, Okayama University

Key Words : Metal Forming, Liquid Lubrication, Finite Element Analysis, Strip Drawing

\section{1.}

塑性加工においては，工具／被加工材界面での摩撩低減 や焼付き防止のために流体润滑剤を用いることが多い.こ の際, 被加工材表面に存在する微小な凹凸は，局所的なミ クロ流体潤滑機構を引き起こし，潤滑性を向上させること が知られている(1)(2). しかしながら，そのような凹凸に よる局所的な潤滑凧举動や，その潤滑性への影響について は，実験的 (3) および解析的 (4) (5) に検討を行った例が幾 つか報告されているものの，末だ不明な点が多く残されて いるのが現状である.

このような背景から本研究は，表面に微小な凹凸を有す る材料の塑性加工に伴う潤滑昘挙動を, 有限要素法を用い て解析的に明らかにすることを最終目的とする.ここでは, その最初の段階として, 微小なポケットを表面に持つ板材 の引抜き加工をモデル化し， 2 次元剛塑性有限要素法を用 いて解析することを試みる，具体的には，潤滑剤ポケット の形状やダイス角度などの条件を変化させ，それらが引抜 きに伴うポケット形状変化や, ポケット内の潤滑剂挙動に 及ぼす影響について検討する。

\section{2. 解析方法}

本研究で用いる引抜き加工の解析モデルを Fig. 1 に示す. 被加工材は相当応力一相当ひずみ関係が

$$
\bar{\sigma}=123 \bar{\varepsilon}^{0.208}
$$

で与えられる金属材料を想定し，その工具との接触面に小 さな潤滑阂ポケットを設ける. 本来, 引抜き加工では材料 が連続的に供給されるが，ここでは解析を容易にするため に，被加工材の長さをポケット部分に影響を与えない程度 $(10 \mathrm{~mm})$ にとどめる.

本モデルでは引抜きダイス角を $\alpha$,引抜き速度を $u$ とし， 板幅は板厚に比べて十分に大きく，寸法が変化しない平面 ひずみ状態と仮定する. また, 被加工材と工具の接触面に は摩擦係数 $\mu$ のクーロン摩擦が县くとする.

潤滑剂ポケットの形状は, 一辺が $d=500 \sim 1100 \mu \mathrm{m}$ で, 引 抜き方向に角度 $\beta$ の斜面を持つ形（Type A, Fig. 2(a)）と，

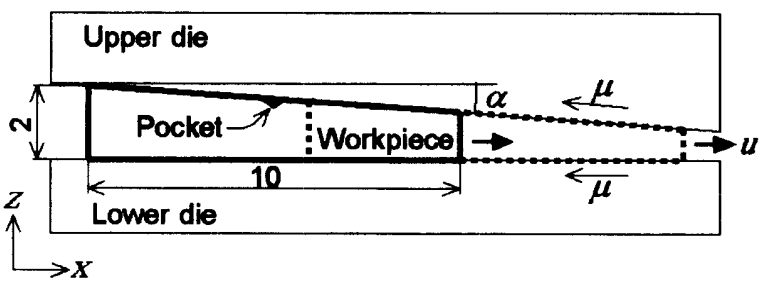

Fig. 1 Model of strip drawing (mm)
その底を平面とした形 (Type B, Fig. 2(b)) の 2 種類とした。 また, Fig. 2(c)のようにポケットは被加工材表面において板 幅方向および長さ方向に一定間隔で並んでいるとした.こ のような問題に対して有限要素法を適用することは簡単で はない. 筷密な解析には 3 次元モデルが有効であるが, 被 加工材全体とポケットの寸法が大きく異なるために, 要素 分割において節点数および要素数を極度に増やさなければ ならず, 計算時間やコスト面で現実的ではない. しかしな がら Fig. 1 のモデルをそのまま 2 次元的に要素分割すると, ポケットは板幅方向に続く菁となり大きな応力集中を招く. そこで, 次のような 3 段階の手順によって解析を行うこと とした.

\section{第 1 段階}

解析には 2 次元剛塑性有限要素法を用い, 平面ひずみ条 件とする. まず, ポケット内部を被加工材と同じ材料と したモデルを用いて解析を行い, ポケット左右端におけ る節点変位を求める.

\section{第 2 段階}

第 1 段階と同じ要素分割でポケット内を潤滑郕（剛粘塑 性体）としたモデルを用いて解析を行う。このとき，ポ ケット左右端の節点には, 第 1 段階で求めた節点変位を 与える.このことは，ポケットの引抜き方向（ $x$ 方向） の変形に対して, ポケットがない部分による拘束を与え ることを意味しており, ポケットが幅方向に続く满状に モデル化されることを防いでいる.この段階の解析にお いて, ポケット周囲の節点変位を全て求めておく.

\section{第3 段階}

潤滑剂ポケットのみを取り出して改めて要素分割したモ デルを用い, その周囲の節点に第 2 段階で求めた節点変 位を与えて解析を行うことにより，ポケット内部での潤 滑剂挙動や応力分布を求める.

この方法を用いて, まずポケット形状を変化させて解析 を行い, 解析方法の妥当性について検討するとともに，そ

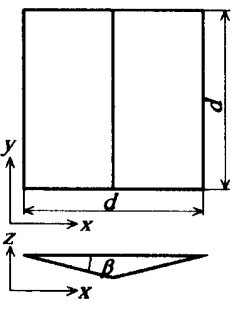

(a) Type A

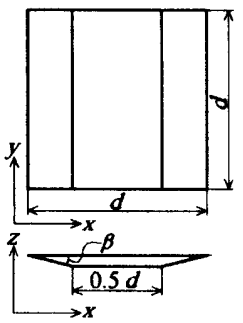

(b) Type B (c) Arrangement of pockets

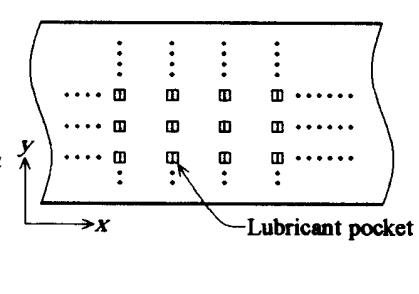

Fig. 2 Shapes of lubricant pockets and their arrangement on workpiece surface 


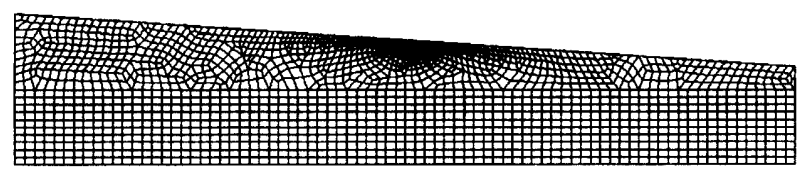

(a) Workpiece

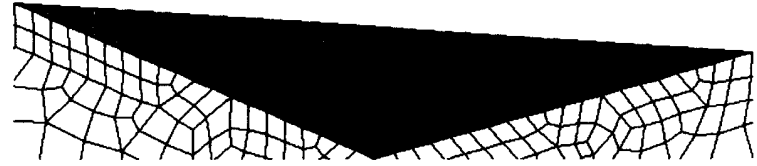

(b) Lubricant pocket

Fig. 3 An example of finite element mesh (1974 elements, 2107 nodes)

れが潤滑剂挙動に及ぼす影響を調べた．被加工材の要素分 割例およびそのポケット部分の拡大図を Fig. 3 に示す. 今 後, さらにダイス角 $\alpha$, ポケット寸法 $d$ およびポケット斜 面角 $\beta$ などを変化させて解析を行う予定である.

なお, 剛塑性有限要素法においては, 润滑剤をニュート ン流体と仮定すると，㣚粘塑性体として取り扱うことがで きる.このとき潤滑剤部分の構成式は,

$$
\sigma_{i j}=2 \eta \dot{\varepsilon}_{i j}-p \delta_{i j}, \quad \eta=\frac{\bar{\sigma}}{3 \dot{\bar{\varepsilon}}}
$$

のようになる ${ }^{(4)}$.ここで $\eta$ は粘度, $p$ は圧力, $\delta_{i j}$ はクロネ ッカーデルタである.

\section{3. 结果と考察}

以下では, 条件をダイス角 $\alpha=4^{\circ}$, 引抜き速度 $u=1 \mathrm{~mm} / \mathrm{s}$, 摩擦係数 $\mu=0.15$, ポケット寸法 $d=0.8 \mathrm{~mm}$ および斜面角 $\beta=20^{\circ}$, 润滑剂粘度 $\eta=1.8 \times 10^{-4} \mathrm{MPa} \cdot \mathrm{s}$ として解析を行った例を示す.

まず,第 1 段階および第 2 段階後の相当応力分布を Fig. 4 に示寸。なお,引抜き開始からの板材の移動量は $x=6 \mathrm{~mm}$ である．ポケット内部を潤滑剤とした第 2 段階では，ポケ ット周囲に大きな応力勾配が現れるものの, 特にポケット から離れた部分においては各段階において相当応力分布に ほとんど違いがないことがわかる．このことは，ポケット に対する板材長さがほぼ充分であることを示している.ま た，板材は摩擦の影響を受けて変形しており，引抜き方向 （図中の右側）に対して等相当応力線が湾曲する傾向が見 られた。

次に第 3 段階における Type A および Type B の潤滑剂ポ ケットの形状変化を Fig. 5, 6に示す. また，加工途中の相 当塑性ひずみ速度の分布を Fig. 7 に示す．ポケットの輪郭 については, 初期に斜面であった辺が徐々に歪むが, Type B

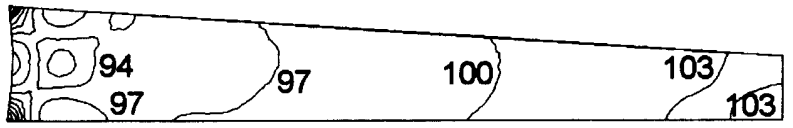

(a) After the first step

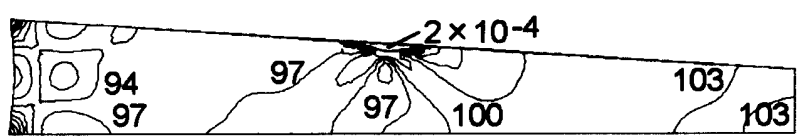

(b) After the second step

Fig. 4 Distribution of effective stress after the each step of analysis $(x=6 \mathrm{~mm}$, Pocket type A)
の底面は加工後もほぼ直線を保っていることがわかる．ま たポケット内部では，全体的に引抜きの後方へ向かう流れ が生じている．一方，相当塑性ひずみ速度分布を見ると， ポケットの前端付近で大きな值を示している．これらのこ とは, 引抜きにおいては前方ほど変形状態が厳しくなるた めに，ポケット内の潤滑剤がそれに応じて後方へ流れるこ とを示唆していると考えられるが, 詳細についてはさらに 異なる加工条件で解析を行うことによって検討する予定で ある.

終わりに，本研究には（財）天田金属加工機械技術振興 財団研究助成（AF-2000005）を受けたことを記して謝意を 表す.

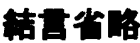

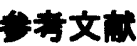

(1) T. Mizuno and M. Okamoto, Trans. ASME, J. of Lubrication Technol., 104 (1982), 53-59.

(2) 池 浩, 塑性と加工, 34-393 (1993), 1075-1081.

（3）小豆島明, 塑性と加工, 39-455 (1998), 1198-1201.

(4) Y. G. Meng, S. Z. Wen and H. Saiki, Wear 160 (1993), 163-170.

（5）小島之夫，機論，67A-656 (2001), 672-677.

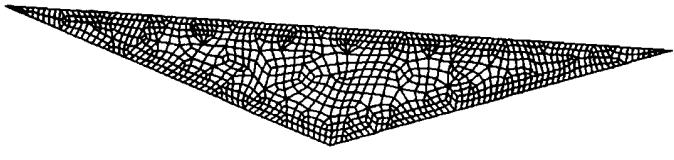

(a) Initial shape

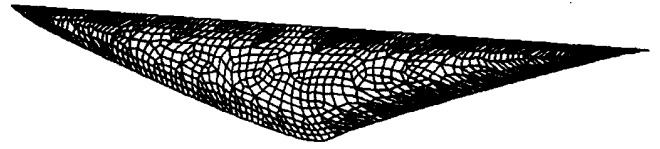

(b) at $x=4.8 \mathrm{~mm}$

Fig. 5 Change in shape of pocket after strip drawing (Type A)

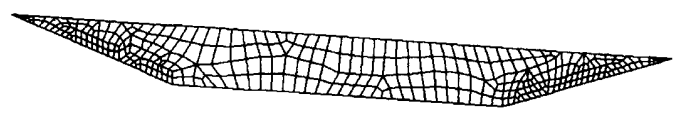

(a) Initial shape

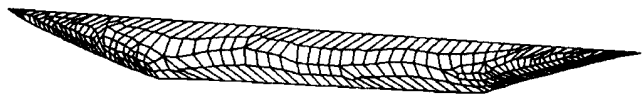

(b) at $x=4.8 \mathrm{~mm}$

Fig. 6 Change in shape of pocket after strip drawing (Type B)

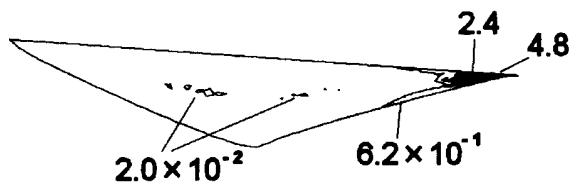

(a) Type A

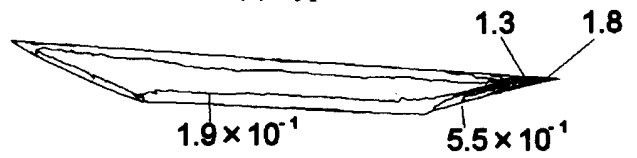

(b) Type B

Fig. 7 Distribution of effective strain rate in lubricant pocket $(x=4.8 \mathrm{~mm})$ 